\title{
Phytochemical screening of Justicia simplex D. Don a valuable medicinal plant extract against Dental pathogens
}

\author{
M. Geetha Eswari ${ }^{1}$, R. Lakshmi Rathi ${ }^{1}$, J. Harini ${ }^{1}$, \\ R. Aruna ${ }^{2}$, V. Balakrishnan ${ }^{1, *}$ \\ ${ }^{1}$ Department of Biotechnology, K.S. Rangasamy College of Technology, \\ Tiruchengode - 637 215, Tamil Nadu, India \\ ${ }^{2}$ Department of Pharmacognosy, Siddha Central Research Institute, Arumbakkam, \\ Chennai - 600 106, Tamil Nadu, India \\ *E-mail address: palanivbalu@gmail.com
}

\begin{abstract}
The plant Justicia simplex D.Don is traditional herb, people used it in different diseases, they treat fever and burning of the body, strengthen the lungs, the teeth and stop vomiting. The plant exhibited more promising bacterial activity against various microorganisms. Hence, in the present study this plant is also tested against the dental pathogens. The plant was extracted from four different solvents was tested for the presence of phytochemicals in it. After analyzing, its antimicrobial activity is tested against fungi and bacteria. Then a dental carrier Streptococcus aureus, Klebsiella pneumonia, Escherichia coli and Pseudomonas aeruginosa which was collected from the K.S.R. Institute for Dental Science and Research. The isolates were used to check the activity against Justicia simplex D.Don. Based on the positive result obtained against various analyses, it is formulated successfully into a tooth paste. The present study on Phytochemical screening of Justicia simplex D.Don a valuable medicinal plant extract against Dental pathogens enables the use of this plant for the formulation of tooth powder against dental pathogens. The result is more effective against dental pathogens by herbal tooth powder.
\end{abstract}

Keywords: Justica simplex; Dental pathogen; Traditional knowledge; Herbal tooth powder

\section{INTRODUCTION}

Medicinal plant is widely used in many clinical diseases. Medicinal plants have a long history of applications and their use is widespread in developed countries. The World Health Organization (WHO) stated that $80 \%$ of the world populations rely mainly on traditional therapies which involves the use of plant extracts (or) their active substances (Seher gur et al., 2006).

Higher plants, as sources of medicinal compounds, have continued to play a dominant role in the maintenance of human health since ancient times (Farombi, 2003; Balamurugan and Balakrishnan, 2013). Many efforts have been made to discovery of new antimicrobial compounds from various kinds of source such as micro-organisms, animals and 
plants. One of such resource is folk medicines. Systematic screening of them may result in the discovery of novel effective compounds (Philip Robinson et al., 2009).

The increasing prevalence of multidrug resistant strains of bacteria and the recent appearance of strains with reduced susceptibility to antibiotics raises untreatable bacterial infections and add urgency to the search for new infection-fighting strategies (Sifradzki et al.1999). Medicinal plants have been used for centuries as remedies for human diseases because they contain compounds of therapeutic value. Recently, the acceptance of traditional medicine as an alternative from of health care and the development of microbial resistance to the available antibiotics have led authors to investigate the antimicrobial activity of medicinal plants (Nostro et al., 2000).

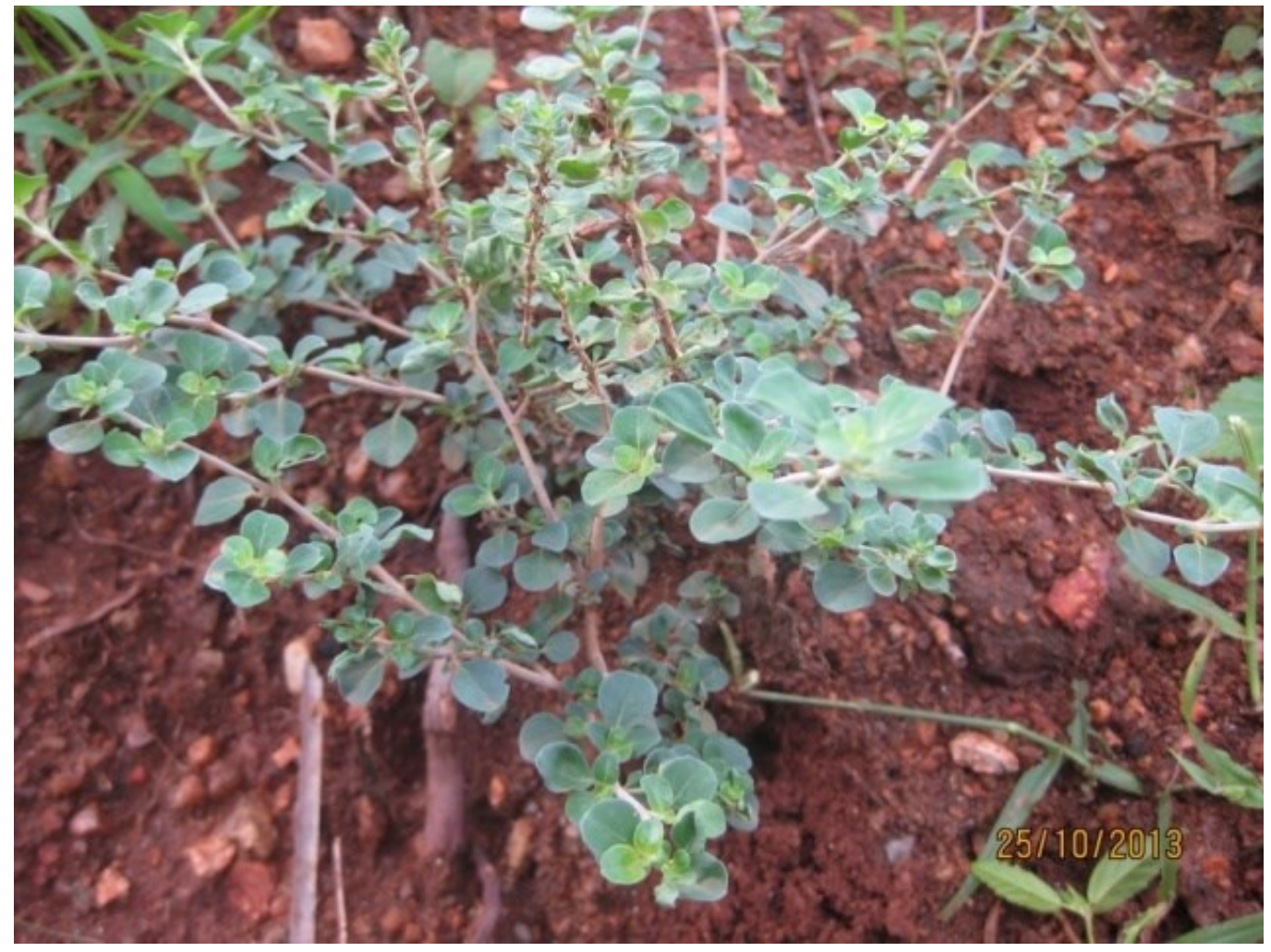

Fig. 1. Habit of Justicia simplex D. Don.

The medicinal plants sectors have projected Tamil Nadu, one of the Southern state, as an "Herbal state". India has made medicinal plants as a commodity of high valuable across the state. There are many aspects of research associated with the medicinal plant sector (Giday el al., 2003; Elavazhagan and Balakrishnan, 2013). Justicia simplex D.Don (Fig. 1) is distribution information from the users of traditional medicinal plants (Sathya bama et al,. 2012). The plant is widely using to the traditional people in different diseases. The leaves contain a bitter and slightly toxic alkaloid, some aromatic amines and $\alpha$ and $\beta$ sitosterol, the roots contain $\beta$ sitosterol (Ghani, 2003). The leaves give strength to the body. The plant is diuretic, stomachic, expectorant, anthelmintic, diaphoretic and aperient; removes indigestion, biliousness, fever and burning of the body,strengthens the lungs, the teeth, stops vomiting; good in diseases of the spleen. Leaf juice is dropped into eyes in case of ophthalmia. Medicinal plants represents an important health and also an economic component of biodiversity of the medicinal component of the flora of any country for conservation 
(Kamalakannan and Balakrishnan, 2009). Dental caries is a common oral bacterial pathology caused by biofilms consisting of microorganisms present on the tooth surface (Allaker and Douglas, 2009). Bacterial infections still pose a considerable health hazard to human beings. Oral infections of bacteria commonly present in the indigenous flora are the etiological factors for disease. Tooth powders are more popular in rural areas.

The constituents of tooth powder and tooth paste are same except that tooth powders do not contain humectants, water and binding agents. The tooth powder is the cleaning of the accessible surface of the teeth (Mithal and Saha, 2000). Natural products have been recently investigated more thoroughly as promising agents for the presentation of oral diseases, especially plaque- related diseases such as dental caries. The present work deals with the phytochemical constituents, antibacterial activity and formulation of herbal tooth powder from the selected medicinal plant Justicia simplex D.Don.

\section{MATERIALS AND METHODS}

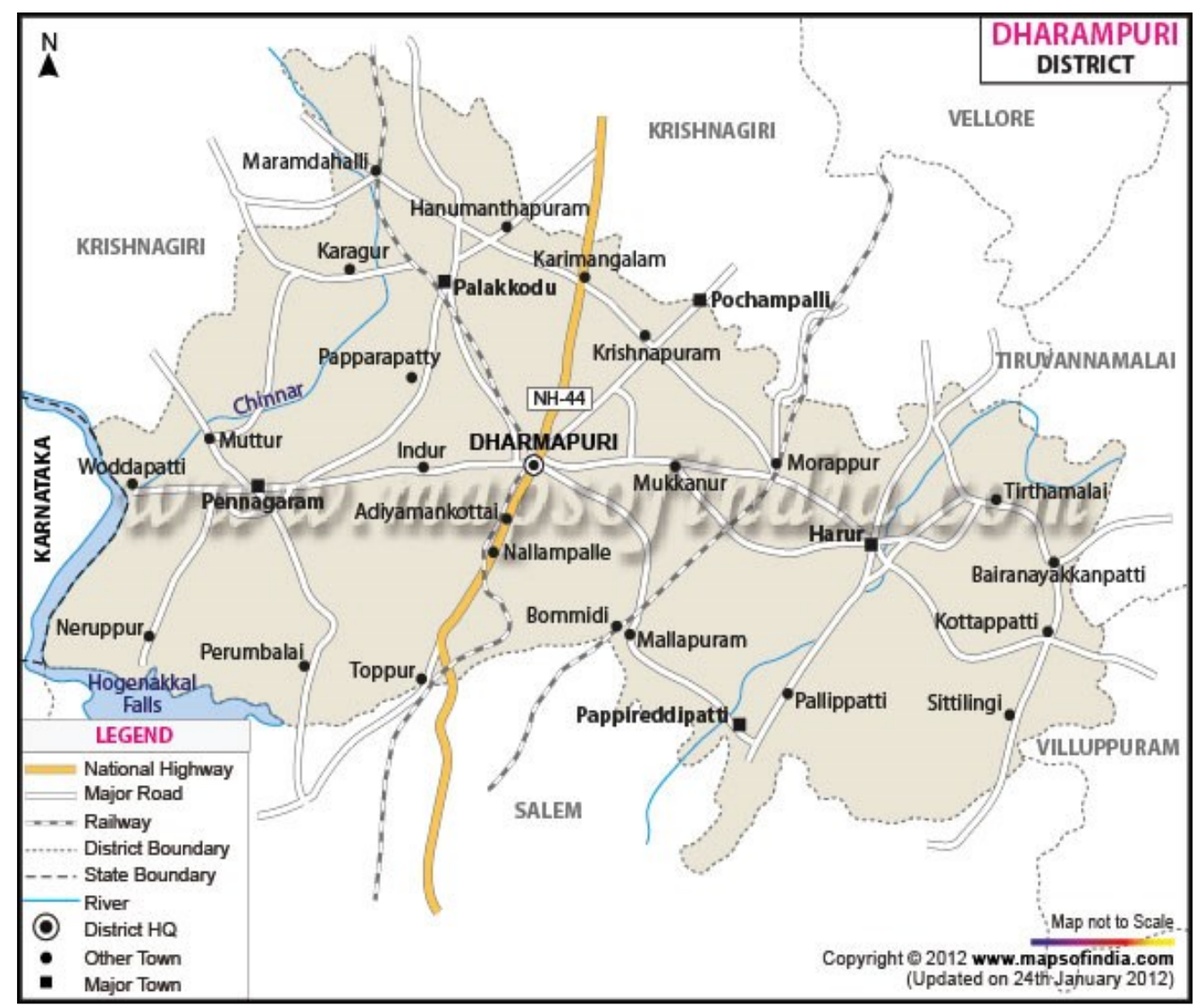

Fig. 2. Map of Dharmapuri district, Tamil Nadu state, India.

The plant leaf was collected from Dharamapuri district (Fig. 2). The collected leaf sample was shade dried under room temperature and the milled into powder by a mechanical grinder. The plant leaf powder was stored in airtight bottle, until further analysis.

The plant Justicia simplex D.Don selected for the present study belongs to the family Acanthaceae. The voucher specimen has deposited in the Department of Biotechnology, K.S. Rangasamy College of Technology, Tiruchengode. 


\section{1. Microorganisms of dental caries}

The dental pathogen was collected and nutrient broth was preferred for sub culture $S$. aureus, $K$. pneumonia, E. coli and $P$. aeruginosa. The microorganisms were used to find out antimicrobial activity.

\section{2. Test microorganisms}

Test microorganisms were collected from MTCC. Test microorganisms Staphylococcus aureus (MTCC 7443), Klebsiella pneumonia (MTCC 7407), Escherichia coli (MTCC 1692) and Pseudomonas aeruginosa (MTCC 2581). The organisms were sub cultured on specific media, procured from HiMedia Laboratory Pvt. Ltd., Bombay, India, recommended for different microorganisms such as different media.

\section{PLANT EXTRACTION METHOD}

\section{1. Extraction}

Five gram of powdered leaf sample was dissolved in $50 \mathrm{ml}$ of ethanol aqueous, Benzene and Hexane separately and kept in a shaker for $24 \mathrm{hrs}$. After $24 \mathrm{hrs}$ ethanol extraction was filtered by using Whatman No. 1 filter paper, extraction was stored in airtight bottles at $5^{\circ} \mathrm{C}$ (Aliyu et al., 2008).

\section{2. Phytochemical Screening}

Standard biochemical methods were followed for phytochemical analysis of the aqueous, ethanol, benzene and hexane extract of the leaves of Justicia simplex as described below:

\section{3. Test for alkaloids (Evans, 1997)}

\section{Mayer reagent}

Two $\mathrm{ml}$ of filtrate extraction mixed with five $\mathrm{ml}$ of $1 \%$ aqueous $\mathrm{HCl}$ and few drops of Mayer reagent was added. Precipitate was obtained.

\section{Mayer's reagent}

Mercuric chloride was dissolved in $30 \mathrm{ml}$ of water and potassium chloride was dissolved in five $\mathrm{ml}$ of water. The two solutions were mixed and made up to $50 \mathrm{ml}$ with water.

\section{Dragendorff's test (Waldi, 1965)}

Two $\mathrm{ml}$ of filtrate and 1 or $2 \mathrm{ml}$ of Dragendorff's reagent was added. A prominent yellow precipitate was formed.

Test of saponins (Chitravadiuv, 2009)

One $\mathrm{ml}$ of extract was dissolved in one $\mathrm{ml}$ of distilled water. Foam was formed.

\section{Test for tannin (Kardong, 2013)}

$10 \%$ of lead acetate solution was added to $0.5 \mathrm{ml}$ of extract solution. The white color precipitate was obtained. 


\section{Test of reducing sugar}

One $\mathrm{ml}$ of filtrate along with Fehling's solution I and II was kept in a water bath for 10 minutes. Red precipitate was formed. This indicates of glycosides and carbohydrates.

\section{Fehling's solution I}

Copper sulphate $(6.932 \mathrm{~g})$ was dissolved in distilled water and made up to $100 \mathrm{ml}$.

\section{Fehling's solution II}

Potassium sodium tartarate (34.6 g) and sodium hydroxide (10 g) was dissolved in water and made up to $100 \mathrm{ml}$.

\section{Test for flavonids}

Extracts was treated with few drops of sodium hydroxide solution. Yellow color was appeared and it indicates the presence of flavonids.

\section{4. Detection of protein and amino acids}

\section{Xanthoproteic test}

Two ml of extracts was treated with few drops of conc. nitric acid. Yellow color was formed which confirms the presence of protein and amino acids.

\section{Ninhydrin test}

To the extract, $0.25 \% \mathrm{w} / \mathrm{v}$ ninhydrin reagent was added and boiled for few minutes.

\section{Test of terpenoid and steroid}

Five $\mathrm{ml}$ of extract solution was mixed in $2 \mathrm{ml}$ of chloroform and $3 \mathrm{ml}$ of conc.sulphuric acid and was added to form a layer.

\section{5. Carbohydrates test}

\section{Molisch test}

Two ml of extract and two drop of molich's was added and mixed well and carefully added one $\mathrm{ml}$ concentrated sulfuric acid along the sides of the tubes in slanting position. Appearance of Violet color ring at the junction of two layers.

\section{6. Antibacterial activity}

\section{Muller Hinton agar medium}

$\begin{array}{lll}\text { Beef infusion } & - & 3 \mathrm{~g} / 1 \text { lit } \\ \text { Starch } & - & 1.5 \mathrm{~g} / 1 \text { lit } \\ \text { Casein hydrolysis } & - & 17.5 \mathrm{~g} / 1 \text { lit } \\ \text { Agar } & - & 17 \mathrm{~g} / 1 \text { lit }\end{array}$




\section{7. Agar well diffusion method}

The antibacterial activity of plant extracts were determined by agar well diffusion method. The Muller Hinton ager 20-25 ml medium was poured in the sterilized petridish and allowed to solidify. $24 \mathrm{hrs}$ bacterial cultures $(S$. aureus, $K$. pneumonia, $P$. aeruginosa and $E$. coli) was spread into the MHA medium and allowed to solidify. Wells of $6 \mathrm{~mm}$ in diameter about $2 \mathrm{~cm}$ apart were punched in the culture medium. Each extract $(2 \mu \mathrm{l})$ was added to the well. Plates were incubated at $37^{\circ} \mathrm{C}$ foe 24 hours. Antibacterial activities were evaluated by measuring inhibition zone diameters. Gentamicin and Amphotericin were used as controls.

\section{8. Tooth powder}

The following drugs are used in formulation of Herbal tooth powder. Clove, Ginger, Asafetida, Amla, Pepper, Justicia simplex leaf, stem, Baking soda, Table soda, Mentha leaf. The material was dried under shade. Powdered it and used for the formulation of herbal tooth powder.

\section{9. Formula for Tooth Powder preparation}

$\begin{array}{lcc}\text { Ingredient } & & \text { Quantity (gm) } \\ \text { Clove } & - & 15 \\ \text { Ginger } & - & 10 \\ \text { Amla } & - & 15 \\ \text { Asafoetida } & - & 05 \\ \text { Pepper } & - & 06 \\ \text { Baking soda } & - & 7.5 \\ \text { Table salt } & - & 2.5 \\ \text { Menthe leaf } & - & 07 \\ \text { Justicia simplex leaf } & - & 17\end{array}$

The ingredient was added in fine powder and preferred herbal tooth powder (Pawar et al., 2011). The formulation was stored in an air tight bottles for further analysis.

\section{10. Agar well diffusion method}

The antibacterial activity of herbal tooth powder extracts were determined by agar well diffusion method. The Muller Hinton ager 20-25 ml medium was poured in the sterilized petridish and allowed to solidify. $24 \mathrm{hrs}$ bacterial culture $(S$. aureus, K. pneumonia, $P$. aeruginosa and $E$. coli) was spread into the MHA medium and allowed to solidify. Wells of 6 $\mathrm{mm}$ in diameter about $2 \mathrm{~cm}$ apart were punched in the culture medium and $100 \mu 1$ of test compound was introduced in well. The plates are incubated in $37{ }^{\circ} \mathrm{C}$ in $48 \mathrm{hrs}$. Microbial growth was determined by measuring the diameter of zone of inhibition in plates. 


\section{RESULTS AND DISCUSSION}

\section{1. Phytochemical analysis}

The phytochemical analysis of the J. simplex extracts showed that the presence of alkaloids, protein, flavonids, amino acids, tannin, carbohydrates, saponins, terpenoid and steroid in aqueous extract. Reducing sugar was absence for all four extract. Reducing sugar, terpenoid and steroid are absent the ethanol extract and other chemical present in the extract. The results showed in Table 1 and 2. The flavonids present in the hexane extract but they absent in the benzene extract. The other chemical compounds are present in the two extractions; the result is showed in Table 3 and 4.

The phytochemical screening was carried out in different test. The result is reducing sugar was absent in the plant extract. The glycosides, tannin, saponins are absent in the methanol extract (Sathya Bama, 2013). The steroid absent in the ethanol, benzene and hexane extracts. The leaf extracts was contains alkaloids, tannin and carbohydrates in all solvents extracts. The plant leaves contain a secondary metabolites compounds.

Chemical constituents are naturally available in plants, the chemical compounds are contributing main role is drug development of many diseases. Tannin present in the plant leaves and degrade the bacteria and fungi.

Table 1. Qualitative phytochemical analysis of Justicia simplex in aqueous Extract.

\begin{tabular}{|c|c|c|c|}
\hline S. No & $\begin{array}{c}\text { Chemical } \\
\text { constituents }\end{array}$ & Phytochemical test & $\begin{array}{c}\text { Aqueous } \\
\text { extract }\end{array}$ \\
\hline \multirow{2}{*}{1} & Alkaloids & Mayer test & + \\
\cline { 3 - 4 } & Protein & Dragendorff's test & + \\
\hline 2 & Terpenoid & $\begin{array}{c}\text { Salkowski test } \\
\text { Salkowski test }\end{array}$ & + \\
\hline 3 & Steroid & Alkaline reagent test & + \\
\hline 4 & Flavonids & Ninhydrin test & + \\
\hline 5 & Amino acids & Fehling's test & - \\
\hline 6 & Reducing sugar & Lead acetate test & + \\
\hline 7 & Tannin & Foam test & + \\
\hline 8 & Saponins & Molich's test & + \\
\hline 9 & Carbohydrates & test &
\end{tabular}

-Negative (absent), + Positive (present) 
Table 2. Qualitative phytochemical analysis of Justicia simplex by Hexane Extract.

\begin{tabular}{|c|c|c|c|}
\hline S. No & $\begin{array}{c}\text { Chemical } \\
\text { constituents }\end{array}$ & Phytochemical test & $\begin{array}{c}\text { Hexane } \\
\text { extract }\end{array}$ \\
\hline \multirow{2}{*}{1} & Alkaloids & Mayer test & + \\
\cline { 3 - 4 } & & Dragendorff's test & + \\
\hline 3 & $\begin{array}{c}\text { Terpenoid } \\
\text { Steroid }\end{array}$ & Xanthoproteic test & + \\
\hline 4 & Flavonids & Salkowski test & + \\
\hline 5 & Amino acids & Ninhydrin test & + \\
\hline 6 & Reducing sugar & Fehling's test & - \\
\hline 7 & Tannin & Lead acetate test & + \\
\hline 8 & Saponins & Foam test & - \\
\hline 9 & $\begin{array}{c}\text { Carbohydrates } \\
\text { test }\end{array}$ & Molich's test & + \\
\hline
\end{tabular}

-Negative (absent), + Positive (present)

Table 3. Qualitative phytochemical analysis of Justicia simplex by Ethanolic extract.

\begin{tabular}{|c|c|c|c|}
\hline S. No & $\begin{array}{c}\text { Chemical } \\
\text { constituents }\end{array}$ & Phytochemical test & $\begin{array}{c}\text { Ethanolic } \\
\text { Extract }\end{array}$ \\
\hline 1 & Alkaloids & Mayer test & + \\
\cline { 3 - 4 } & Protein & Xanthoproteic test & + \\
\hline 2 & Terpenoid & $\begin{array}{c}\text { Salkowski test } \\
\text { Salkowski test }\end{array}$ & - \\
\hline 3 & Steroid & Alkaline reagent test & + \\
\hline 4 & Flavonids & Ninhydrin test & + \\
\hline 5 & Amino acids & Fehling's test & - \\
\hline 6 & Reducing sugar & Lead acetate test & + \\
\hline 7 & Tannin & Foam test & + \\
\hline 8 & Saponins & Molich's test & + \\
\hline 9 & Carbohydrates & & \\
\hline
\end{tabular}

-Negative (absent), + Positive (present) 
Table 4. Qualitative phytochemical analysis of Justicia simplex by Benzene extract.

\begin{tabular}{|c|c|c|c|}
\hline S. No & $\begin{array}{c}\text { Chemical } \\
\text { constituents }\end{array}$ & Phytochemical test & $\begin{array}{c}\text { Benzene } \\
\text { extract }\end{array}$ \\
\hline \multirow{2}{*}{1} & Alkaloids & Mayer test & + \\
\cline { 3 - 4 } & Protein & Dragendorff's test & + \\
\hline 2 & Terpenoid & $\begin{array}{c}\text { Salkowski test } \\
\text { Salkowski test }\end{array}$ & + \\
\hline 3 & Steroid & Alkaline reagent test & - \\
\hline 4 & Flavonids & Ninhydrin test & - \\
\hline 5 & Amino acids & Fehling's test & - \\
\hline 6 & Reducing sugar & Lead acetate test & + \\
\hline 7 & Tannin & Foam test & - \\
\hline 8 & Saponins & Molich's test & + \\
\hline 9 & Carbohydrates test & & \\
\hline
\end{tabular}

- Negative (absent), + Positive (present)

\section{2. Antibacterial activity}

The four solvents were using to find out the antibacterial activity. The subculture of microorganism using to zone of inhibition was measured in diameter in $\mathrm{mm}$. the zone inhibition result is shown in Table 5 and Fig 3. Ethanol extract was given more antibacterial activity they given to $16 \mathrm{~mm}$ zone was absorbed in $E$. coli and hexane extract is not given to zone inhibition for test microorganisms. Aqueous extract was given to the antibacterial activity was absorbed for $E$. coil and $K$. pneumonia. The zone of inhibition given to the maximum of diameter of $4 \mathrm{~mm}$ in $E$. coli. The antibacterial activity is more effect in ethanol extract of Justicia simplex. $10 \mu \mathrm{l}, 20 \mu \mathrm{l}$ and $30 \mu \mathrm{l}$ of extract was not given to the zone of inhibition. $70 \mu \mathrm{l}$ of extract was given an inhibition $0.1 \mathrm{~mm}$ diameter for ethanol extracts.

The native inhabitants were well-versed with the utilization of plants of their surrounding by their long trial and error method of using the herbal plants (Balakrishnan et al., 2009). 
Table 5. Antibacterial activities for different extract of plant against dental pathogen.

\begin{tabular}{|c|c|c|c|c|}
\hline \multirow{2}{*}{ Source } & \multicolumn{4}{|c|}{ Zone of Inhibition (mm) } \\
\cline { 2 - 5 } & $\begin{array}{c}\text { Ethanol } \\
\text { extract }\end{array}$ & $\begin{array}{c}\text { Benzene } \\
\text { extract }\end{array}$ & Hexane extract & $\begin{array}{c}\text { Aqueous } \\
\text { extract }\end{array}$ \\
\hline S. aureus & $15 \mathrm{~mm}$ & $8 \mathrm{~mm}$ & No zone & No zone \\
\hline K. pneumonia & $10 \mathrm{~mm}$ & $6 \mathrm{~mm}$ & No zone & $1 \mathrm{~mm}$ \\
\hline E. coli & $16 \mathrm{~mm}$ & $12 \mathrm{~mm}$ & No zone & $4 \mathrm{~mm}$ \\
\hline P. aeruginosa & $12 \mathrm{~mm}$ & $5 \mathrm{~mm}$ & No zone & No zone \\
\hline
\end{tabular}

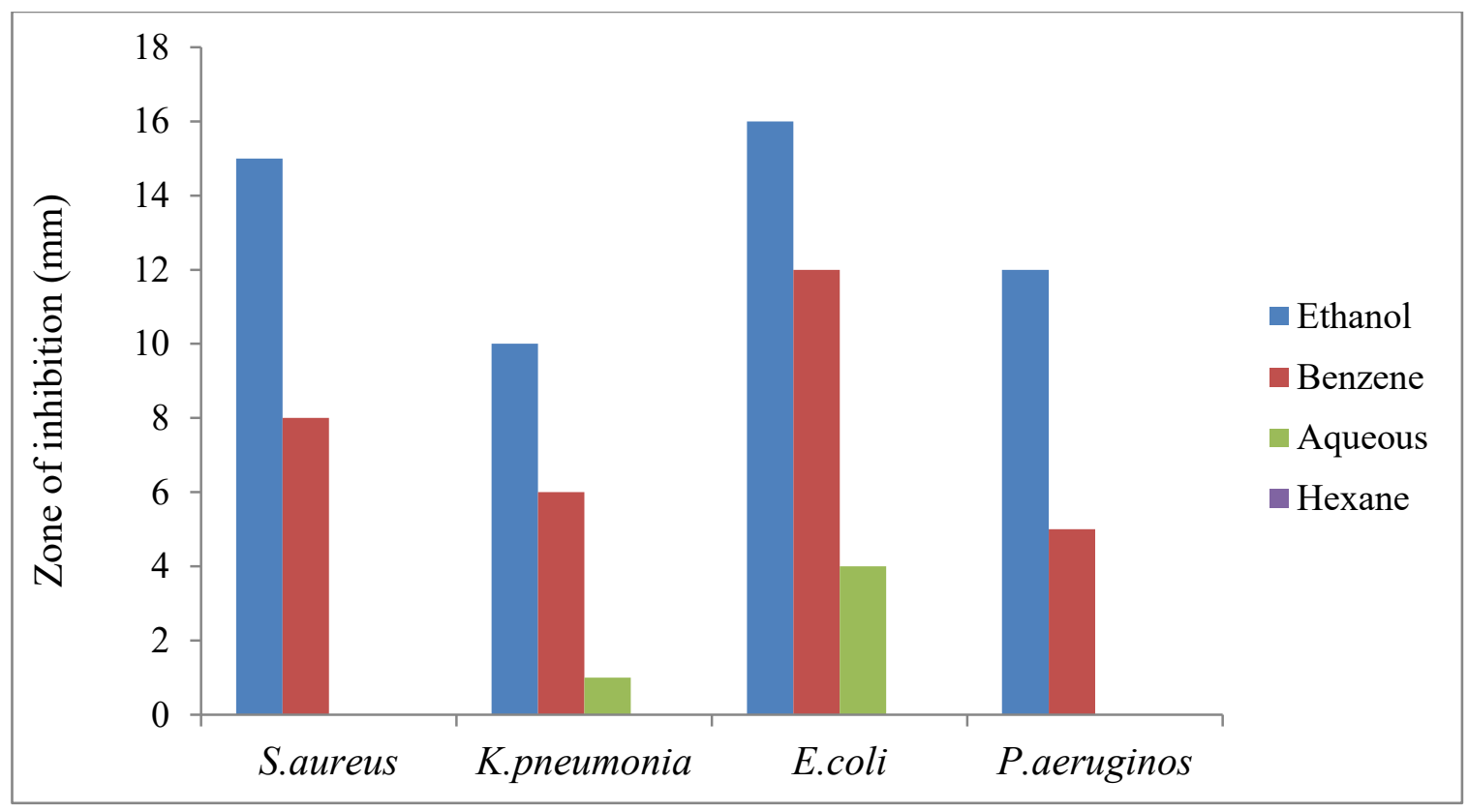

Fig. 3. Antibacterial activity of Justicia simplex.

\section{3. Tooth powder}

The formulation of herbal tooth powder was prepared by using ingredients such as Justicia simplex leaf, pepper powder, ginger, clove powder, amla, Mentha leaf, table salt and baking powder were mixed well. The formulation of herbal tooth powder The J. simplex is more effective of the dental pathogens. Mentha leaf is given to the freshness of the mouth. The pepper, ginger added to the flavour of the herbal tooth powder. Clove flowers were naturally contain antibacterial activity. There is no side effectby using herbal tooth powder during brushing of the teeth.

There is an increasing demand for the production of health care medicines and cosmetic items from plant origin based on the ancient knowledge in folk remedies (Venkatesan et al., 2005). 


\section{CONCLUSIONS}

The present research concluded that the herbal plant is used for the tooth powder development of dental caries disease. The investigation of antibacterial activity of herbal plant extracts of Justicia simplex showed that the ethanol extract shows promising antibacterial activity against dental bacterial pathogens when compared to the benzene, hexane and water extracts. The activity of Justicia simplex was due to the presence phytochemical compounds like alkaloids, proteins, flavonoids, amino acids, tannins, carbohydrates, saponins, terpenoid and steroids.

Since all the tested extracts of J. simplex were highly effective against two of the tested dental caries. The alcoholic extracts of formulation herbal tooth powder, showed effective results against dental pathogens. The formulation herbal tooth powder is given a more effective compare to the other tooth powder. The ingredients used in the formulate tooth powder does not show any toxic effects.

\section{Acknowledgemnt}

The authors are thankful to K.S.R. Institute for Dental Science and Research for providing samples. The authors are also acknowledge the Management, Principal and Professor \& Head of the Department of Biotechnology for providing necessary laboratory facilities to carry out the work effectively.

\section{References}

[1] Aliyu A.B, Musa, Abdullahi M.S, Oyewale A.O, Gwarzo U.S, Nig Journ. Pharm. Sci. 7(1) (2008) 1-8.

[2] A llaker P., Douglas M., International Journal Antimicrobial Agents 33(1) (2009) 8-13.

[3] BalakrishnanV., Prema P., Ravindran K. C., Philip Robinson J., Global Journal of Pharmacology 3(1) 2009.

[4] Balamurugan V., Balakrishnan V., Global Journal of Bioscience and Biotechnology 2(2) (2013) 243-247.

[5] Chitravadivu C., Manian S., Kalaichelvi K., Middle-East Journal of Scientific Research 4(3) (2009) 144-146.

[6] Elavazhagan T., Balakrishnan V., International Journal of Basic and Life Sciences 1(2) (2013) 1-7.

[7] Evans W.C., Pharmacology Harcourt Brace and Company, Asia,Singapore (1997) 226.

[8] Farombi E., African journal of Biotechnology 2 (2003) 662-671.

[9] Ghani A., Medicinal plants of Bangladesh - chemical constituents and uses, $2^{\text {nd }}$ edition, The Asiatic society of Bangladesh, Dhaka (2003).

[10] Giday M., Asfaw Z., Elmquist T., Woldu Z., Journal of ethnopharmacology 85 (2003) 43-52.

[11] Kamalakannan K., Balakrishnan V., South India.Journal of phytology 1(2) (2009) 108-111.

[12] Kardong D., Upadhyaya S., Saikia L.R., Journal of Pharmacy research (2013) 179-182. 
[13] Mithal B.M., Saha R.N., A hand book of cosmetics (2000) 203-215.

[14] Nostro A., Germano M.P., Angelo U.D., Marino A., Cannatelli M.A., Letters in applied microbiology 30 (2000) 379-384.

[15] Philip Robinson J., Balakrishnan V., Sebastin Raj J., John Britto S., Advances in Biological Research 3(5-6) (2009) 185-187.

[16] Sathya Bama S., Sankaranarayanan S., Bama P., Ramachandran J., Bhuvaneswari N., Jayasurya Kingsley, Academic journal 7(20) (2013) 1452-1460.

[17] Seher Gur, Nazmi Gur, World Journal of Agricultural sciences 2(4) (2006) 439-442.

[18] Sifradzki K., Roberts R.B., Haber S.W., Tomasz A., N. Engl. J. Med. 340 (2000) 517-523.

[19] Venkatesan K., Balakrishnan V., Ravindran K. C., Devanathan V., SIDA 21(4) (2013) 2243-2248.

[20] Waldi D., Spray reagents for thin layer Chromatography-a laboratory hand book. Acadmic Press inc., Publishers, New York, U.S.A, (1965) 491. 